\title{
Deteksi Mastitis Subklinis Pada Kambing Peranakan Etawah Di Kelurahan Kalipuro, Banyuwangi
}

\author{
Detection Of Subclinical Mastitis In Peranakan Etawah Goat In Kalipuro Village, \\ Banyuwangi
}

\author{
Adelita Putri Sevitasari ${ }^{1 *}$, Mustofa Helmi Effendi ${ }^{2}$, Prima Ayu Wibawati ${ }^{2}$ \\ ${ }^{1}$ Pendidikan Profesi Dokter Hewan, \\ ${ }^{2}$ Departemen Kesehatan Masyarakat Veteriner, \\ Fakultas Kedokteran Hewan, Universitas Airlangga, \\ Kampus C Mulyorejo, Surabaya, Jawa Timur, Indonesia 60115 \\ *Corresponding author: adelitasevita11@gmail.com
}

\begin{abstract}
Abstrak
Mastitis adalah penyakit yang terjadi akibat infeksi pada kelenjar ambing. Mastitis subklinis merupakan tipe mastitis yang tidak menunjukkan gejala klinis. Tujuan dari penelitian ini adalah untuk mendeteksi mastitis subklinis pada peternakan Kambing PE dengan menggunakan metode California Mastitis Test sebagai penelitan awal untuk mendapatkan data awal kejadian kasus mastitis subklinis di Kelurahan Kalipuro, Banyuwangi. Penelitian ini merupakan penelitian deskriptif. Deteksi dilakukan dengan pengambilan sampel susu pada kambing PE secara purposif dan direaksikan reagen CMT diputar secara sirkuler selama 1015 detik. Pengamatan hasil reaksi sampel susu dan reagen ditentukan berdasarkan perubahan konsistensi dengan adanya masa pengentalan. Hasil penelitian menunjukkan bahwa tingkat kejadian kasus mastitis subklinis sebesar $82.76 \%$. Faktor terjadinya mastitis subklinis dapat dipengaruhi oleh manajemen perkandangan dan pemerahan peternakan, karena sanitasi dan hygiene berpengaruh pada tingkat kontaminasi bakteri.
\end{abstract}

Kata kunci: California Mastitis Test, mastitis, Peranakan Etawah

\begin{abstract}
Mastitis is a disease which occur as result of the infection in mammary gland. Subclinical mastitis is a type of mastitis which does not show clinical symptoms. The purpose of this study was to examine subclinical mastitis on PE Goat livestock by using the California Mastitis Test method as a preliminary study to obtain preliminary data on cases of subclinical mastitis in Kalipuro Village, Banyuwangi. This research was a descriptive research. Detection was done by taking milk samples on PE purposively and was reacted with CMT reagents which were circulated circularly for 10-15 seconds. The observation of the reaction results of milk and reagent samples were determined based on consistency changing with the coagulation period. The results showed that the incidence of subclinical mastitis was $82.76 \%$. The subclinical mastitis factor was influenced by cowshed management and milking of livestock, because sanitation and hygiene influenced to the level of bacterial contamination.
\end{abstract}

Key words: California Mastitis Test, mastitis, Peranakan Etawah

Received: 20 Maret 2019

Revised: 16 April 2019

Accepted: 11 Juli 2019

\section{PENDAHULUAN}

Kambing Peranakan Etawah merupakan kambing hasil dari persilangan Kambing Kacang dan Kambing Etawah. Kambing PE termasuk kambing dwiguna yang dimanfaatkan sebagai kambing pedaging dan produksi susu (Ratya dkk, 2017). Masyarakat Kelurahan Kalipuro salah satu daerah yang memanfaatkan hasil produksi susu kambing PE sebagai konsumsi serta dianggap dapat dijadikan untuk pengobatan pada gangguan pencernaan.

Penyakit yang sering ditemukan pada peternakan terutama ternak perah yaitu penyakit mastitis (Suwito dkk, 2013). Mastitis merupakan penyakit radang pada kelenjar ambing yang dapat disebabkan oleh bakteri atau jamur yang bersifat pathogen (Isnel and Sukru, 2012). 
Mastitis ada dua jenis yaitu mastitis klinis dan mastitis subklinis. Mastitis klinis adalah mastitis yang memiliki gejala klinis dan menunjukkan perubahan pada susu, sedangkan mastitis subklinis tidak terdapat gejala klinis dan tidak terdapat perubahan pada susunya. Mastitis dapat mengakibatkan kerugian pada nilai ekonomis maupun pada aspek kesehatan (Najeeb et al., 2013). Mastitis subklinis dapat mengakibatkan penurunan kuantitas dan kualitas pada produksi susu. Perubahan kuantitas dan kualitas susu pada ternak penderita mastitis subklinis dapat dipengaruhi oleh meningkatnya jumlah sel somatik maupun tingkat infeksi pada ambing.

Deteksi untuk mengetahui kejadian mastitis subklinis dapat dilakukan monitoring jumlah sel somatic dengan pemeriksaan laboratorium (Sudarwanto et al., 2006) Metode yang dapat dilakukan dengan mudah dan cepat yaitu dengan uji California Mastitis Test (CMT).

Berdasarkan latar belakang penelitian diatas, penulis bermaksud untuk mengetahui tingkat kejadian kasus mastitis pada kambing PE di Kelurahan Kalipuro dengan menggunakan metode CMT, sebagai penelitian dasar kasus mastitis subklinis di Kelurahan Kalipuro Kecamatan Kalipuro Kabupaten Banyuwangi.

\section{METODE PENELITIAN}

Metode penelitian deskriptif dilakukan dengan screening test yaitu menggunakan metode CMT. Data yang didapatkan disajikan secara deskriptif. Metode sampling yang digunakan yaitu metode purposif sampling dan jumlah sampel yang diambil pada penelitian ini yaitu 58 ekor kambing per 2 kuartir. Pemilihan kambing sesuai kriteria yang telah ditentukan yaitu: (1) kriteria kandang yang menggunakan bahan baku kayu dan bambu, (2) umur kambing PE 2-3 tahun, (3) kambing yang aktif diperah.

Penelitian ini dilakukan secara langsung di kandang peternakan kambing PE di Kelurahan Kalipuro Kecamatan Kaliputo Kabupaten Banyuwangi. Pengambilan sampel dilakukan pada pagi hari pukul 06.00-09.00 sesuai dengan waktu pemerahan. Sampel susu diambil secara aseptic dari ambing kambing dengan cara dibersihkan terlebih dahulu menggunakan air bersih, kemudian dikeringkan menggunakan kasa steril. Pengambilan sampel untuk deteksi mastitis dilakukan oleh pemilik kambing. Pancaran susu kambing pertama dibuang dan pengambilan sampel susu menggunakan susu pancaran ke-2 sampai ke-6 yang ditampung pada paddle test setiap kuartirnya (Suryowardojo, 2012). Paddle test dimiringkan hingga batas garis yang terdapat pada alas sehingga susu yang tersisa di paddle test sebanyak $2 \mathrm{ml}$. Kambing yang telah diambil susunya sebagai sampel akan dilanjukan pemerahan oleh peternak.

Pengujian sampel susu menggunakan reagen CMT dengan perbandingan sesuai aturan pakai pada kemasan yaitu $2 \mathrm{ml}$ sampel susu : $3 \mathrm{ml}$ reagen CMT. Dilakukan putaran secara horizontal sirkuler atau memutar agar sampel susu dan reagen dapat tercampur sampai homogen selama 10 detik serta diamati hasil reaksinya dengan melihat perubahan kosistensi dari reaksi susu dan reagen dengan memiringkan paddle untuk melihat masa jel yang terbentuk pada hasil positif. Hasil uji CMT postif $1(+)$, positif $2(++)$, positif $3(+++)$, dan positif 4 $(++++)$ semua dicatat sebagai hasil positif.

Analisis data yang digunakan yaitu analisis deskriptif. Data diperoleh dari hasil uji CMT untuk deteksi mastitis subklinis diolah dan disajikan secara deskriptif.

\section{HASIL DAN PEMBAHASAN}

Peternakan A dari 8 ekor kambing PE dengan hasil positif 7 ekor dan 1 ekor negatif. Hasil dari peternakan B terdapat 42 ekor kambing PE dengan hasil positif 35 ekor dan 7 ekor negatif. Hasil peternakan $\mathrm{C}$ terdapat 4 ekor kambing PE dengan hasil semua positif. Hasil peternakan D terdapat 4 ekor kambing dengan hasil 2 ekor positif dan 2 ekor negatif (Tabel 1).

Hasil uji CMT dengan pembandingan antara hasil positif dan negative (Tabel 1). Hasil negatif mastitis subklinis dengan ciri-ciri pada pereaksian sampel susu kambing PE dengan reagen CMT konsistensi tetap cair dan pada pemutaran secara sirkuler dapat merata, sehingga pada saat dimiringkan hasil reaksi sampel jatuh 
Tabel 1. Hasil deteksi mastitis subklinis pada Kambing PE

\begin{tabular}{|c|c|c|c|c|c|c|}
\hline \multirow{3}{*}{ Peternakan } & \multirow{3}{*}{$\mathbf{n}$} & \multicolumn{4}{|c|}{ Mastitis Subklinis } & \multirow{3}{*}{$\begin{array}{l}\text { Total positif } \\
\text { mastitis (\%) }\end{array}$} \\
\hline & & \multicolumn{3}{|c|}{ Positif (+) } & \multirow{2}{*}{$\begin{array}{c}\text { Negatif } \\
(-)\end{array}$} & \\
\hline & & Puting kanan kiri & Puting kanan & Puting kiri & & \\
\hline A & 8 & 7 & 2 & 1 & 1 & 87.5 \\
\hline B & 42 & 23 & 32 & 7 & 7 & 83.5 \\
\hline $\mathrm{C}$ & 4 & 4 & 4 & - & - & 100 \\
\hline $\mathrm{D}$ & 4 & 1 & 2 & 2 & 2 & 50 \\
\hline Total & 58 & & Jumlah & & & 82.76 \\
\hline
\end{tabular}

dengan konsistensi cair dan tidak melekat pada alas paddle test. Hasil positif mastitis subklinis dengan ciri-ciri pada pereaksian sampel susu kambing PE dengan reagen CMT pada pemutaran secara sirkuler hasil reaksi sampel tidak dapat merata pada paddle test dan jika dimiringkan akan jatuh dengan adanya masa gel atau pengentalan. Perubahan konsistensi pada uji CMT disebabkan oleh reagen yang mengandung arylsufonate yang bereaksi dengan memecah inti sel somatic atau sel leukosit yang terdapat pada susu sehingga mengakibatkan terjadinya pengentalan. Semakin tinggi derajat mastitis yang ditampilkan pada hasil uji CMT menunjukkan jumlah sel somatik yang terdapat pada susu (Nurdin, 2007).

Mastitis merupakan penyakit peradangan pada ambing yang disebabkan infeksi bakteri yang menyerang sel kelenjar susu (Mirdayanti dkk, 2008). Hasil deteksi sangat tinggi dengan hasil yang didapat menunjukkan bahwa hasil positif mastitis subklinis sebesar $82.76 \%$ dari keseluruhan peternakan yang digunakan sebagai pengambilan sampel susu Kambing PE. Penyakit masitits subklinis yang tidak menunjukkan gejala klinis dan tidak menunjukkan perubahan pada susunya. Peternak tidak menyadari akan adanya penyakit mastitis subklinis pada peternakannya, namun dapat diperhatikan pada hasil produksi susu. Karena pada penyakit mastitis subklinis dapat mengakibatkan kerugian dengan menurunnya tingkat produksi susu dengan skala bertahap (Seegers et al., 2003).

Mastitis subklinis dapat disebabkan oleh berbagai faktor salah satunya dari manajemen perkandangan dan manajemen pemerahan yang kurang diperhatikan. Salah satu penyebabnya kontaminasi bakteri yang berasal dari agen pathogen yang secara normal berasal dari feses, alas kandang, pakan, dan dari kebersihan pemerah. Sebab mastitis subklinis merupakan penyakit kompleks yang dapat disebabkan oleh bakteri, khamir, dan kapang (Subronto, 2003). Beberapa bakteri pada umumnya sebagai penyebab terjadinya mastitis klinis dan subklinis diantaranya yaitu Streptococcus agalactiae, Streptococcus dysgalactiae, Streptococcus uberis, Staphylococcus aureus, Staphylococcus epidermidis, Escherichia coli, Escherichia freundii, Aerobacter aerogenes, dan Klebsiella pneumoniae (Poeloengan, 2010; Pradika et al., 2019). Menurut Jayarao dan Wolfgang (2003), pada hasil penelitiannya patogen mayor yang menyebabkan mastitis yaitu Staphylococcus aureus, Streptococcus agalactiae dan Mycoplasma sp. Menurut pernyataan (Heras et al., 1999) pada kejadian penyakit mastitis pada penelitiaanya sebagai penyebab terjadinya mastitis klinis dan subklinis pada kambing disebabkan oleh bakteri patogen Pseudommonas aeroginosa. Penelitian yang dilakukan oleh Contreras et al., (2007) menyatakan bahwa penyebab mastitis klinis dan subklinis pada kambing yaitu Staphylococcus spp. non hemolytic 38.2\%, Staphylococcus aureus $11.0 \%$, Escherichia coli $1.6 \%$ dan Pseudomonas spp. 1.2\%. Selain bakteri, mastitis klinis dan subklinis juga dapat disebabkan oleh Candida sp. dan Mycoplasma sp.

Upaya menurunkan mastitis subklinis secara tidak langsung dapat celup puting (teat dipping) dengan antiseptik untuk menurunkan tingkat kejadian mastitis subklinis pada peternakan (Mahardika, 2016). Antiseptik yang digunakan untuk celup puting berperan sebagai penghambat pertumbuhan mikroorganisme yang bermultiplikasi dilubang puting (Zalizar dkk, 2018). 


\section{KESIMPULAN}

Tingkat kejadian kasus mastitis subklinis pada kambing Peranakan Etawah dengan deteksi menggunakan metode CMT di Kelurahan Kalipuro, Banyuwangi sebesar $82.76 \%$.

\section{UCAPAN TERIMA KASIH}

Peneliti mengucapkan terimakasih kepada petugas Dinas Pertanian Banyuwangi telah mendampingi penelitian di Kelurahan Kalipuro.

\section{DAFTAR PUSTAKA}

Isnel, N.B., Sukru, K. 2012. Isolation of Microorganism From Goats with Subclinical Mastitis and Detection of Antibiotics Susceptibility. J Anim. Health Prod. Hyg., 1(2), 106-112.

Mahardika, H.A. 2016. Pengaruh Suhu Air Pencucian Ambing Dan Teat Dipping Terhadap Jumlah Produksi, Kualitas Dan Jumlah Sel Somatik Susu Pada Peternakan Sapi Peranakan Fresian Holstein. Buletin Peternakan, 40(1), 11-19.

Mirdhayanti, I., Jully, H., Khaidar, U.P. 2008. Mutu Susu Segar di UPT Ruminansia Besar Dinas Peternakan Kabupaten Kampar Provinsi Riau. J. Peternakan, 5(1), 14-21.

Najeeb M.F., Anjum, A.A., Ahmad, M.U.D., Khan, H.M., Ali, M.A., Sattar, M.M.K. 2013. Bacterial Etiology of Subclinical Mastitis in Dairy Goats and Multiple Drug Resistance of The Isolates. J. Anim. Plant Sci., 23(6), 1541-1544.

Nurdin, E. 2007. Pengaruh Pemberian Tongkol Bunga Matahari (Helianthus annuus l.) Dan Probiotik Terhadap Penurunan Derajat Mastitis Pada Sapi Perah Fries Holland Penderita Mastitis Sub-Klinis. Jurnal Indones. Trop. Anim. Sci., 32(2), 76-79.
Pradika, A.Y., Chusniati, S., Purnama, M.T.E., Effendi, M.H., Yudhana, A., Wibawati, P.A. 2019. Uji Total Escherichia coli pada Susu Sapi Segar di Koperasi Peternak Sapi Perah (KPSP) Karyo Ngremboko Kecamatan Purwoharjo Kabupaten Banyuwangi. J. Med. Vet., 2(1), 1-6.

Ratya, N., Taufik, E., Arief, I.I. 2018. Chemical, Physical and Microbiological Characteristics of Etawa Crossbred Goat Milk in Bogor. Jurnal Ilmu Produksi dan Teknologi Hasil Peternakan, 5(1), 1-4.

Seegers, H., Fourichon, C., Beaudeau, F. 2003. Production Effects Related To Mastitis And Mastitis Economics In Dairy Cattle Herds. Vet. Res., 34(5), 475-491.

Subronto. 2003. Ilmu Penyakit Ternak I. Gajah Mada University Press. Yogyakarta. p701.

Sudarwanto, M., Latif, H., Noordin, M. 2006. The Relationship of The Somatic Cell Counting to Sub-Clinical Mastitis and to Improve Milk Quality. $1^{\text {st }}$ International AAVS Scientific Conference. Jakarta, 1213.

Suryowardojo, P. 2012. Penampilan Kandungan Protein dan Kadar Lemak Susu Pada Sapi Perah Mastitis Friesian Holstein. J. Exp. Life Sci., 2(1), 44.

Suwito, W., Wahyuni, A.E.T.H., Widagdo, S.N., Bambang, S. 2013. Isolasi dan Identifikasi Bakteria Mastitis Klinis Pada Kambing Peranakan Etawah. J. Sain Vet., 31(1), 5053.

Zalizar, L., Sujono, Dian, I., Yovi, A.S. 2018. Kasus Mastitis Subklinis pada Sapi Perah Laktasi di Kecamatan Pujon Kabupaten Malang. Jurnal Ilmu-Ilmu Peternakan, 28(1), $35-41$. 